\title{
GEOMETRY OF NANOPARTICLES AS A DETERMINANT OF THEIR CYTOTOXICITY
}

\section{Leonenko N. S., Demetska O. V., Tkachenko T. Yu, Leonenko O. B.}

\author{
SI «Institute for Occupational Health of NAMS of Ukraine», Kyiv
}

Background. Today the study of toxicity of nanoparticles of different elements is of primary significance, as 1) a growing number of workers contact professionally with nanomaterials; 2) the number of nanotechnology products is growing up, which, in turn, are spread widely among consumers and can cause adverse effects on human health and the environment. Toxicological properties of nanoparticles, in turn, are determined by chemical and physical properties, including geometric characteristics: shape, critical diameter, crystal lattice parameters, etc.

Objective. To investigate the effect of geometry (shape, size) of silver nanoparticles on their cytotoxicity.

Materials and methods. Silver nanoparticles of different shape (sphere, decahedron, triangle) and size (13, 20, 40 nm), stabilized by carboxylates, have been used. A particle size was determined, using Analysette 12 Dynasizer (Fritch, Germany). The cytotoxicity was studied, using toxicity analyzer AT-05 (Russia).

Results. It was established that $40 \mathrm{~nm}$ spherical as well as $40 \mathrm{~nm}$ decahedral silver nanoparticles in native form did not demonstrate any cytotoxicity. It is determined that $17 \mathrm{~nm}$ spherical silver nanoparticles are more toxic than $17 \mathrm{~nm}$ decahedral ones, as they show a cytotoxic effect in the concentration, in which decaehedral are not toxic. It is found that $20 \mathrm{~nm}$ triangular silver particles show a cytotoxic effect in 1:10 dilution and no effect in 1:1 dilution.

Conclusion. The geometry of nanoparticles, their shape and size (critical diameter), in particular, is one of important determinants of their toxicity, which should be taken into consideration in risk assessment. In this, there are not any general regulations concerning their effect on toxic properties of nanoparticles. So, their interrelations should be established individually in each specific case.

Key words: silver nanoparticles,critical diameter of nanoparticles, cytotoxicity

\section{Introduction}

At present time one of priorities of occupational health researches is nanotoxicology. The study of toxicity of nanoparticles, comprised of various elements, is of great importance due to: (1) a large number of workers, which contact professionally with nanomaterials; (2) a permanent growing of nanotechnology products, their wide spreading among consumers and possible adverse effects on human health and the environment. There is a need to carry out an efficient toxicological risk assessment, associated with various non-tested nanoparticles and their variations in size, composition, shape, etc [3, 6].

Nanotoxicology studies an interaction between nanostructures and biological systems, aiming to reveal a correlation between a nanoparticle physical and chemical properties (such as size, shape, surface characteristics, composition, and aggregation degree) and a toxic response of biological structures. So, a nanosystem toxicity includes physiological, physicochemical and molecular aspects. It is known, that nanoparticles can penetrate into the body through hematoencephalic barrier, skin, respiratory tract as well as through gastrointestinal tract, characterized by a long half-life, accumulation in the bone marrow, central and peripheral nervous systems, organs of alimentary tract, lungs, liver, kidneys, and lymph nodes [9]. A problem of the so-called nanotoxicity is of special attention, because toxicity of nanoparticles cannot be determined through simple transfer of the known toxicological data to nanoscales.

It is known that physicochemical properties of nanoparticles cause formation of a pro-oxidative medium in cells, causing instability of the energy system, and, as a result, nanoparticles induce adverse biological effects from inflammation initiation to cell death [5]. In turn, the toxicity of metal nanoparticles relates directly on their physicochemical properties, i.e. on the size and, respectively, on the free surface area, which stipulates high chemical activity of the particle and its high ability to penetrate into the body. Thus, the smaller is the particle size, the bigger is the surface area and degree of toxicity of the material. In particular, in nano- and macroparticles of the same composition the number of physicochemical properties differs significantly. For instance, considerable decrease of the melting temperature is observed in nanoparticles of many 
metals and semiconductors (Ag, Au, Pb, Sn, In, Bi, Ga, CdS); solidity of thread-like crystals and fibrils can be several times higher as compared to solidity of 'macroscopic' bodies; nanoparticles express high chemical activity, which appears in acceleration of chemical reactions with them (such nanoparticle property is used in catalyst development); phases which are not revealed in macromaterials can be observed in nanoparticles [2].

It should be considered that properties of dispersed particles with dimensions larger than a critical diameter (dcr) are determined by the laws of the classic physics, while properties of particles with dimensions smaller than dcr - by those of the quantum mechanics. Thus, dispersed particles gain a new quality: they become nanoparticles and their compact consolidation makes it possible to produce nanomaterials. So, a maximal diameter of a dispersed particle is critical, below which the laws of the quantum mechanics begin to operate under the predominant action of free atom valences on the phase interface, which, by turn, stipulates drastic changes of material's properties. For different substances, i.e. metals, dcr ranges from 17 to $20 \mathrm{~nm}(30-40 \mathrm{~nm})[1]$. The comparison of a nanoparticle actual size with der is very important for assessment of its physicochemical properties and biological effects. In practice, nanoparticles are usually available in complex mixtures. Moreover, even chemically inert nanoparticles can induce adverse effects on the body, due to tiny size. However, it should be mentioned that der is still not taken into account in biomedical studies.

Thus, nanoparticles of the same chemical composition and of various size show different physicochemical and, respectively, toxicological properties. These properties depend not only on size, adhesive, catalytic and electrical parameters of nanoparticles, but also on their geometry. In view of this the purpose of the work was to study the effect of geometric peculiarities (shape, size) of silver nanoparticles on their cytotoxicity.

\section{Materials and methods}

Silver nanoparticles of different shape (sphere, decahedron, triangle) and size (13, 20, $40 \mathrm{~nm})$, stabilized by carboxylates, were used. A particle size was determined with the use of Analysette 12 Dynasizer (Fritch, Germany). The cytotoxicity was studied with the toxicity analyzer AT-05 (Russia).

\section{Results and discussion}

The cytotoxicity of silver nanoparticles of different shape (sphere, decahedron, triangle) and size (13, 20, $40 \mathrm{~nm}$ ), stabilized by carboxylates, was studied. At present, there is no any universal test-system able to reveal all possible effects of artificial nanomaterials. So, test kits, where there is used different test-organisms (bacteria, algae, protozoa, Crustacea, fishes, plants, etc), find wide applications in practice. The data, obtained by express-methods (study of cytotoxicity), do not diminish the importance of traditional toxicological studies on nanosafety but provide for preliminary information on cytotoxicity of nanomaterials, with which workers contact professionally.

In the express-method on cytotoxicity testing by the toxicity analyzer AT-05 (Russia) there is used an accessible, inexpensive, and standard biological material (bull's spermatozoids). The method makes it possible to investigate non-sterile extracts and to obtain results in less than $3 \mathrm{~h}$.

The cytotoxicity degree of a substance is calculated by a toxicity index It (in \%), which amounts to the ratio of spermatozoids mobility in the analyzed sample to spermatozoids mobility in the control sample. The analyzed sample is considered as cytotoxic, when It ranges from 1 to $70 \%$ or exceeds $120 \%$.

In the work it is determined that $40 \mathrm{~nm}$ spherical silver nanoparticles as well as $40 \mathrm{~nm}$ decahedron silver nanoparticles do not show a cytotoxic effect in the native form. The investigation of smaller nanoparticles demonstrated that spherical silver nanoparticles were more toxic than decahedron ones, since in the equal concentrations the former showed the cytotoxic effect and the latter one none (Table).

These data correspond to the results of our own experiments as well as to the results of other studies, which confirm that toxicity increases under particle's diameter decrease [3, 9]. This correlation can be explained by relations between a particle size and a free surface area. The decreasing of a nanoparticle size leads to exponential increasing of the percentage of surface atoms. For example, the decrease of a particle diameter from $30 \mathrm{~nm}$ to $3 \mathrm{~nm}$ increases a percentage of surface atoms from 10 to $50 \%$ [5]. It should be noted that It value at the level $119 \%$ for the $17 \mathrm{~nm}$ spherical particles in dilution $1: 100$ is interpreted formal as non-toxic, but actually represents the so-called 'grey zone' and, thus, does not exclude adverse effects at the cell level. Interpreting 
Table

Cytotoxicity of silver nanoparticles of various size and shape

\begin{tabular}{|l|c|c|c|c|c|c|}
\hline \multirow{2}{*}{$\begin{array}{c}\text { Silver } \\
\text { nanoparticles }\end{array}$} & \multicolumn{2}{|c|}{ Concentration } & \multicolumn{4}{c|}{ IT, $\mathbf{c}$} \\
\cline { 2 - 7 } & particles/ml & $\mathbf{m g} / \mathbf{m l}$ & native & $\mathbf{1 : 1}$ & $\mathbf{1 : 1 0}$ & $\mathbf{1 : 1 0 0}$ \\
\hline Spheres $40 \mathrm{~nm}$ & $6 \cdot 10^{10}$ & 0,03 & 105,3 & & & \\
\hline Decaedra $40 \mathrm{~nm}$ & $6 \cdot 10^{10}$ & 0,01 & 109 & & & 119 \\
\hline Spheres $17 \mathrm{~nm}$ & $6 \cdot 10^{10}$ & 0,14 & 1,9 & 11,5 & 57,5 & 110,8 \\
\hline Decaedra $13 \mathrm{~nm}$ & $6 \cdot 10^{10}$ & 0,03 & 35,13 & 62,18 & 102,7 & 112 \\
\hline Triangle $20 \mathrm{~nm}$ & $4 \cdot 10^{10}$ & & 92,3 & 113,4 & 123,7 & \\
\hline
\end{tabular}

our results in the context of a nanoparticle critical diameter, we can hypothesize that $40 \mathrm{~nm}$ spheres and decahedrons appear to be non-toxic due to their 'non-critical' diameter.

The results of experiments, showing the effect of silver nanoparticles of different size and geometry (plate, sphere, thread) on the fish embryo cells, have been presented by researchers from the USA [4]. They have shown that plate-shaped nanoparticles are the most toxic owing to surface defects, which increase a particle reactivity. The results of defects of packing of the crystal lattice as well as 'point' defects of the crystal silver is a trigger in contacts with cells of the oxidative stress. At the same time nanospheres have shown a higher cytotoxic effect than nanothreads, but only in high particles concentrations. In the other study it was demonstrated that rod-shaped gold nanoparticles were more toxic than cube-shaped ones, and spheric nanoparticles were less toxic and characterized by better biodistribution [8].

As regards $20 \mathrm{~nm}$ triangle silver nanoparticles they showed a cytotoxic effect (activation of test-cells mobility) in 1:10 dilution of the native solution, however were less toxic in 1:1 dilution, even though their concentration in the native solution was lower than concentrations of spheres and decahedrons. The latter can be explained by that the crystal lattice parameters can effect properties of nanoparticles, which, in turn, depend on a particle's size and shape. The latter needs theoretical and experimental justification in collaboration with physicists, in the first place. But it can be hypothesized that the manifestation of the cytotoxic effect in triangle nanoparticles after dilution of the native solution can cause changes in the atom surfaces, which can be shift as a whole. Such uncontrolled agglomeration can change an initial particle size and shape accidentally and drastically.

It should be mentioned that a nanoparticle shape can be important in nanomaterial manufacturing. For example, the shape of nanoparticles, which interact with light, should be taken into account in developing optical limiting devices for protection of sensitive subjects from the laser radiation. The widely used coatings in these devices are superfine films, composed of nanoparticles. The coating properties can be changed by altering the size and shape of nanoparticles. Such coatings are used as filters: nanoparticles are placed in the nodes of the solid matrix. German scientists [10] have been found that the optical limiting devices on the base of metal spherical nanoparticles are the most effective, because they are characterized by the low threshold of 'switching on' with a strong attenuation.

Moreover, the shape of nanoparticles is important in optimization of drug dosage as well as in the targeted delivery of nanomedicines to tumor cells. Up to this day it was considered that the delivery of an active medicinal substance can be realized only by spherical or granular nanoagents, however multiple modeling and experimental studies on introduction of different nanoparticles gave important practical results. It is found, in particular, that extended cylindrical particles can reach cells and move more effectively inside of them [11].

These studies emphasize an important tendency: geometry of nanoparticles is important in their toxicity. Therefore accumulation of the data in this field would help in future to 'update' nanotechnologies for improving their safety for human and the environment. Particularly, now a method is under development, allowing to watch shape changes of nanoparticles in their growing. The understanding of nanoparticle evolution of various forms could help to predict and control future electronic and catalytic properties of the producing nanomaterial [7].

Therefore, the obtained results show that the geometry of nanoparticles can effect the cytotoxicity parameters and require individual clarification and studies for each specific type of nanoparticles. 


\section{Conclusions}

1. Geometry of nanoparticles is one of essential determinants of their cytotoxicity, which should be taken into account in the process of nanomaterial manufacturing and in risk assessment. Moreover, there are no general regulations concerning its effect on nanoparticle toxicity, so these relations need to be defined individually in each specific case.

2. It is found that $40 \mathrm{~nm}$ spherical silver particles as well as $40 \mathrm{~nm}$ decahedron silver particles

\section{References}

1. Vakhrushev, A. A., Fedotov, A. Yu., Shushkov, A. A., Shushkov, A. V. 2011, "Modeling metal nanoparticle formation, studying structural, physicochemical properties of nanoparticles and nanocomposites", Proceedings of TulSU. Natural Sciences, no. 2, pp. 241253 (in Russian).

2. Khamidulina, H. H., Davydova, Yu. O. 2011, "International approaches to assessment of toxicity and hazards of nanoparticles and nanomaterials", Toksikologichesky vestnik, no. 6, pp. 53-57 (in Russian).

3. Balbus, J. M., Maynard, A. D., Colvin, V. L. 2007, "Meeting Report: Hazard assessment for nanoparticles Report from an interdisciplinary Workshop», Envir. Health Persp., Vol. 115, no. 11, pp. 1664-1669.

4. George, S., Lin, Z. Ji, Thomas, C. R. 2012, «Surface defects on plate-shaped silver nanoparticles contribute to its hazard potential in a fish gill cell line and zebrafish embryos", ACS Nano, Vol. 6, no. 5, pp. 3745-3759.

\section{Література}

1. Вахрушев А. А Моделирование формирования наночастиц маталлов, исследование структурных, физико-химических свойств наночастиц и нанокомпозитов / А. А. Вахрушев, А. Ю. Федотов, А. А. Шушков, А. И. Шушков. - 2011 . - № 2. - С. 241-253.

2. Хамидулина Х. Х. Международные подходы к оценке токсичности и опасности наночастиц и наноматериалов / Х. Х. Хамидулина, Ю. О. Давыдова // Токсикологический вестник. - 2011. -№ 6. - С. 53-57.

3. Balbus J. M. Meeting Report: Hazard assessment for nanoparticles - Report from an interdisciplinary Workshop / J. M. Balbus, A. D. Maynard, V. L. Colvin // Envir.Health Persp. - 2007. - Vol. 115, № 11. - P. 16641669.

4. Surface defects on plate-shaped silver nanoparticles contribute to its hazard potential in a fish gill cell line and zebrafish embryos / S. George, S. Lin, Z. Ji, C. R. Thomas // ACS Nano. - 2012. - Vol. 6, № 5. P. 3745-3759. have not expressed any cytotoxicity in the native form.

3. It was defined that $17 \mathrm{~nm}$ spherical silver nanoparticles were more toxic than $17 \mathrm{~nm}$ decahedral ones, as in equal concentrations the first expressed a cytotoxic effect and the latter had none.

4. $20 \mathrm{~nm}$ triangular silver particles appeared to show a cytotoxic effect in 1:10 dilution of the native solution, but were not toxic in the native form and in $1: 1$ dilution.

5. Bokyung, Kong, Ji Hyun Seog. 2011, «Experimental considerations on the cytotoxicity of nanoparticles", Nanomedicine (Lond), Vol. 6, no. 5, pp. 929-941.

6. Lee, N. 2012, "Nanotechnology and occupational health in Korea", Asian - Pacific Newslett on Occup Health and Safety, no. 19, pp. 60-61.

7. Liu, G. 2013, «Delineating the pathways for the sitedirected synthesis of individual nanoparticles on surfaces", PNAS, no. 110, pp. 887-891.

8. Sun, Y. N., Sun, Y. N., Wang, C. D., Zhang, X. M. 2011, "Shape dependence of gold nanoparticles on in vivo acute toxicological effects and biodistribution", J. Nanosci. Nanotechnol, Vol.11, no. 2, pp. 1210-1216.

9. Sur, I. 2010, «Interaction of multi-functional silver nanoparticles with living cells», Nanotechnology, Vol .21, no. 17 , p. 175104.

10. http://sfiz.ru/page.php?al=uchenye_vyjasnili_ chto_f

11. http://www.pnas.org

5. Bokyung Kong. Experimental considerations on the cytotoxicity of nanoparticles / Kong Bokyung, Ji Hyun Seog // Nanomedicine (Lond). - 2011. - Vol. 6, № 5. - P. 929-941.

6. Lee N. Nanotechnology and occupational health in Korea / Lee N. // Asian - Pacific Newslett on Occup Health and Safety. - 2012. - № 19. - P. 60-61.

7. Liu G. Delineating the pathways for the site-directed synthesis of individual nanoparticles on surfaces / Liu G. // PNAS. - 2013. - № 110. - P. 887-891.

8. Sun Y. N. Shape dependence of gold nanoparticles on in vivo acute toxicological effects and biodistribution / Y. N. Sun, C. D. Wang, X. M. Zhang // J. Nanosci. Nanotechnol. - 2011. - Vol. 11, № 2. - P. 1210-1216.

9. Sur I. Interaction of multi-functional silver nanoparticles with living cells / Sur I. // Nanotechnology. - 2010. - Vol. 21, №17. - P. 175104.

10. http://sfiz.ru/page.php?al=uchenye_vyjasnili_ chto_f

11. http://www.pnas.org 
ヘеоненко Н. С., Аемешкая А. В., Ткаченко Т. Ю., Аеоненко О. $Б$.

\section{ГЕОМЕТРИЧЕСКИЕ ХАРАКТЕРИСТИКИ НАНОЧАСТИШ КАК АЕТЕРМИНАНТЫ ШИТОТОКСИЧЕСКОГО АЕЙСТВИЯ}

\section{ГУ «Институт меАицины труда НАМН Украины», г. Киев}

Состояние проблемы. Сегодня исследования токсичности наночастиц различных элементов имеет первостепенное значение, поскольку, во-первых, большое количество рабочих имеет профессиональный контакт с наноматериалами, во-вторых, растет количество продуктов нанотехнологий, которые в свою очередь, получают распространение среди рядовых граждан и могут оказывать неблагоприятное воздействие на здоровье населения и состояние окружающей среды. В свою очередь, токсикологические свойства наночастиц обусловлены как химическими, так и физическими свойствами, среди которых существенное значение могут играть геометрические характеристики (форма, критический диаметр, параметры кристаллической решетки и др.).

Цель исследования. Исследовать влияние геометрических характеристик наночастиц серебра (форма, размер) на цитотоксичность.

Материалы и методы исследования. Наночастицы серебра различной формы, стабилизированные карбоксилатами («сферы», «декаэдры», «треугольники»), и размера (13, 20, 40 нм). Размер частиц измеряли с помощью наносайзера Fritch (Германия). Исследование цитотоксичности проводили на анализаторе токсичности АТ- 05 (Россия).

Результаты. Установлено, что наночастицы серебра 40 нм сферической формы и наночастицы серебра 40 нм в форме декаэдров не обнаружили цитотоксического эффекта в нативной форме. Было установлено, что наночастицы серебра сферической формы размером 17 нм являются более токсичными, чем декаэдры 17 нм, поскольку демонстрировали эффект в концентрации, в которой декаэдры были нетоксичными. Установлено, что наночастицы серебра 20 нм в форме треугольников демонстрируют цитотоксический эффект при разведении нативного раствора 1:10 при отсутствии цитотоксического эффекта в нативной форме и при разведении 1:1.

Bыводы. Геометрические характеристики наночастиц, в частности, форма и размеры (критический диаметр), являются одними из важных детерминант их цитотоксичности, которые следует учитывать при оценке риска. При этом не существует общих закономерностей относительно их влияния на токсические свойства наночастиц, поэтому эти взаимосвязи следует устанавливать отдельно в каждом индивидуальном случае.

Ключевые слова: наночастицы серебра, критический диаметр наночастиц, цитотоксичность

Меоненко Н. С., Мемешыка О. В., Ткаченко Т. Ю., Меоненко О. Б.

\section{ГЕОМЕТРИЧНІ ХАРАКТЕРИСТИКИ НАНОЧАСТИНОК ЯК АЕТЕРМІНАНТИ Читотоксичної АIї}

\section{$\Delta$ У «Інститут меАицини праші НАМН України», м. Київ}

Стан проблеми. Сьогодні дослідження токсичності наночастинок різних елементів має першочергове значення, оскільки, по-перше, велика кількість працівників має професійний контакт із наноматеріалами, по-друге, зростає кількість продуктів нанотехнологій, які, у свою чергу, отримують розповсюдження серед пересічних громадян та можуть чинити несприятливий вплив на здоров'я населення та довкілля. У свою чергу, токсикологічні властивості наночастинок обумовлені як хімічними, так і фізичними властивостями, серед яких суттєве значення можуть відігравати геометричні характеристики (форма, критичний діаметр, параметри кристалічної решітки та ін.).

Мета дослідження. Дослідити вплив геометричних характеристик наночастинок срібла (форма, розмір) на цитотоксичність.

Матеріали та методи дослідження. Наночастинки срібла, стабілізовані карбоксилатами різної форми («сфери», «декаедри», «трикутники»), та розміру (13, 20, 40 нм). Розмір частинок вимірювали за допомогою наносайзера Fritch (Німеччина). Дослідження цитотоксичності проводили на аналізаторі токсичності AT-05 (Росія).

Результати. Встановлено, що наночастинки срібла 40 нм сферичної форми та наночастинки срібла 40 нм у формі декаедрів не виявили цитотоксичного ефекту в нативній формі. Було встановлено, що наночастинки срібла сферичної форми розміром 17 нм є більш токсичними, ніж декаедри 17 нм, оскільки демонстрували ефект у концентрації, у якій декаедри є нетоксичними. Встановлено, що наночастинки срібла 20 нм у формі трикутників демонструють цитотоксичний ефект при розведенні нативного розчину 1:10 за відсутності цитотоксичного ефекту в нативній формі та при розведенні 1:1.

Висновки. Геометричні характеристики наночастинок, зокрема, форма та розміри (критичний діаметр) є одними 3 важливих детермінант їхньої цитотоксичності, які слід враховувати при оцінці ризику. При цьому не існує загальних закономірностей щодо їхнього впливу на токсичні властивості наночастинок, тому ці взаємозв'язки слід встановлювати окремо в кожному індивідуальному випадку.

Ключові слова: наночастинки срібла, критичний діаметр наночастинок, цитотоксичність

Надійшла: 27.01.2014 p.

Contact person: Leonenko N.S., taliya@meta.ua, +380-67-999-2983 